\title{
Jurnal Penelitian dan Pengukuran Psikologi
}

Volume 10, Nomor 1, April 2021

http://doi.org/10.21009/JPPP

CATATAN EDITOR:

MEMOTRET WAJAH PSIKOLOGIS MASYARAKAT INDONESIA:

PERAN PENTING KONSEP DAN PENGUKURAN

PSIKOLOGI YANG ULAYAT

\author{
Karel Karsten Himawan* \\ *Editor Jurnal Penelitian dan Pengukuran Psikologi \\ Fakultas Psikologi, Universitas Pelita Harapan
}

DOI: https://doi.org/10.21009/JPPP.101.01

Alamat Korespondensi:

karel.karsten@uph.edu

\begin{abstract}
Alat ukur merupakan elemen utama dalam studi-studi di bidang psikologi, khususnya yang berpedoman pada paradigma positivisme. Namun mayoritas studi psikologi di Indonesia masih berpedoman pada konsep serta pengukuran psikologi Barat, sehingga kurang akurat dalam memotret realita psikologis yang sebenarnya terjadi. Dalam tulisan ini, secara singkat saya mendeskripsikan peran sentral pengukuran dalam ilmu psikologi dengan memanfaatkan pendekatan historis. Selanjutnya, tulisan ini mendiskusikan pentingnya mempertimbangkan konteks ulayat dalam penelitian psikologi di Indonesia, yang diharapkan dapat menginspirasi studi-studi pengembangan konsep psikologi yang khas Indonesia.
\end{abstract}

\section{Keywords}

Penelitian psikologi, pengukuran, sensitivitas budaya, standarisasi, ulayat

\section{Psikologi dan Pengukuran}

Untuk sebuah ilmu psikologi, dengan objek studi yang abstrak dan hipotetikal, diskusi tentang pengukuran terkesan sebagai hal yang paradoks. Masyarakat awam tentu berpikir bagaimana mengukur perasaan, persepsi, atau intensi seseorang melakukan sesuatu. Namun di saat yang sama, pengukuran telah menjadi bagian penting dalam sejarah perkembangan ilmu psikologi. Isu tentang skala dan pengukuran merupakan elemen utama untuk riset-riset psikologis yang berpijak pada paradigma positivisme - paradigma yang berfokus pada menemukan cara paling akurat dan objektif dalam memotret fenomena (Harrits, 2011).

Meski tes-tes psikologi baru mulai berkembang pesat di Abad ke-20 (Domino \& Domino, 2006), namun sejarah telah lama mencatat upaya manusia untuk menjadikan tes dan pengukuran sebagai refleksi atas kondisi psikologis. Catatan sejarah pada Kitab HakimHakim (ditulis dalam kurun waktu abad ke-3 SM hingga ke $10 \mathrm{M}$ ), yang mengompilasikan teks Masoret, Septuaginta, dan Naskah Laut Mati, mendeskripsikan bagaimana tes verbal sederhana digunakan untuk mengidentifikasi individu dari Suku Efraim, dengan meminta partisipan menyebut kata syibolet. Orang Efraim akan mengucapkan sibolet (Wainer, 1987). Di kitab yang sama, Gideon juga menggunakan sampel perilaku sebagai dasar tes dalam memilih

$\overline{\text { Jurnal Penelitian dan Pengukuran Psikologi, Vol. 10, No. 1, April } 2021}$ 


\section{Karel Karsten Himawan}

pasukan perang. Dari 32,000 pasukan perang, Gideon membuat sistem seleksi sederhana dengan mengobservasi cara minum prajurit tersebut: mereka yang menghirup air dari tangannya dipilih, sedangkan mereka yang berlutut untuk minum tidak. Terkumpullah 300 orang dan fakta bahwa mereka menang perang boleh jadi menunjukkan jenis tes paling praktis dan valid di masa itu! Dari catatan lain, sejak tahun 2200 SM, sejarah mencatat pengetesan sudah menjadi prosedur baku dalam memilih pegawai negeri sipil (PNS) di Cina (Domino \& Domino, 2006).

Upaya pengukuran psikologis yang lebih sistematis mulai mendapat perhatian di Prancis pada tahun 1740-an untuk keperluan diagnosis klinis, diikuti dengan pembentukan laboratorium psikologi pertama pada tahun 1879 oleh Wilhelm Wundt di Jerman. Nuansa pengukuran psikologis di Jerman lebih berfokus pada pendekatan nomotetik (berfokus pada menemukan definisi "normal"), sedangkan di Inggris, arah pengukuran psikologis lebih difokuskan pada pendekatan idiografik (berfokus pada tipologi dan keunikan individual). Di Amerika Serikat, pendekatan terhadap pengukuran psikologis lebih berfokus ke orientasi praktis (aplikatif). Meski dengan pendekatan yang berbeda, ada pola yang sama di mana pengukuran psikologis awalnya berfokus pada aspek kemampuan kognitif, namun kemudian berkembang ke skala dan pengukuran psikologis yang mengukur aspek emosi dan persepsi individu.

\section{Dua Isu Penting dalam Pengukuran Psikologi}

Ada dua isu utama tentang sistem pengukuran psikologi yang kerap dikritisi dalam rangka merumuskan kesimpulan yang paling akurat: standarisasi dan sensitivitas.

Standarisasi skor, yang menjadi awal terbentuknya norma, memungkinkan interpretasi terhadap nilai individu dengan dibandingkan dengan individu lainnya. Bukan hanya itu, standarisasi juga memberi informasi penting dalam mendefinisikan "normalitas" - umumnya disepakati ketika skor seseorang berada di antara persentil 16 hingga 84 (+/- 1 standar deviasi). Namun, sampai sejauh mana perbandingan skor antar individu menyajikan infromasi yang bermakna? Memang penting untuk mengetahui performa seorang anak di dalam kelasnya. Akan
Catatan Editor

tetapi, apakah penting membandingkan performa seorang anak di suatu kelas di kawasan pedalaman Kalimantan, misalnya, dengan performa anak usia yang sama yang tinggal di Brisbane?

Maka dari itu, selain standarisasi, sensitivitas juga merupakan hal yang penting untuk dipertimbangkan dalam konsep pengukuran. Dalam hal ini, sensitivitas mengacu kepada kelompok usia, gender, etnis, dan kondisi geografis. Sebuah skala psikologi perlu cukup sensitif terhadap budaya, misalnya, sehingga skor seseorang tidak hanya diinterpretasikan sebagai lebih tinggi atau lebih rendah, tetapi lebih pentingnya ialah sebagai skor yang merepresentasikan keunikan budaya individu tersebut.

\section{Mempertimbangkan Unsur Ulayat dalam Penelitian dan Pengukuran Psikologi}

Lebih daripada memberikan batasan dalam membandingkan skor antar individu, budaya juga menjadi faktor penting dalam mendefinisikan konsep-konsep psikologis. Pengembangan konsep serta pengukuran psikologis yang sensitif terhadap budaya, terutama dalam konteks Indonesia masih kurang mendapat perhatian. Hampir satu dekade sejak isu mengenai pentingnya menghidupkan psikologi yang ulayat dikemukakan (Sarwono, 2012), belum terlihat adanya upaya nyata yang signifikan dalam mengembangkan konsep serta pengukuran psikologi yang benar-benar khas, lahir dari konteks masyarakat lokal. Kebanyakan studi-studi psikologi masih meminjam teori serta konsep psikologi Barat yang dicocokkan dalam konteks masyarakat Indonesia. Dalam uraian berikut, secara singkat saya akan mengilustrasikan tiga konsep psikologi yang dikonstruksikan dari budaya Barat serta mengkritisi relevansinya dalam konteks ulayat Indonesia: kebahagiaan, religiositas, dan katarsis.

Kebahagiaan (atau kesejahteraan psikologis; well-being) merupakan salah satu topik yang paling banyak diteliti di Indonesia. Alat ukur yang populer digunakan untuk mengukur kebahagiaan ialah Satisfaction With Life Scale (SWLS) (Diener, Emmons, Larsen, \& Griffin, 1985), di mana kebahagiaan diukur melalui respons seseorang terhadap lima 
pertanyaan umum tentang kepuasan hidupnya. Meski studi internasional telah mengkonfirmasi validitas dan reliabilitas alat ukur ini (Tomás, Gutiérrez, Sancho, \& Romero, 2015; Wu, Chen, \& Tsai, 2009), apakah butir pada alat ukur ini merepresentasikan definisi kebahagiaan orang Indonesia pada umumnya? Bagi orang Indonesia, misalnya, kebahagiaan pada orang dewasa kerap dikaitkan dengan kesesuaian dengan ekspektasi masyarakat terhadap dirinya, misalnya menikah (Himawan, 2019). Berpacaran saja tidak cukup untuk membuat seseorang lebih puas dengan hidupnya daripada melajang (Himawan, 2020). Jadi, secara konseptual, definisi kebahagiaan sebagaimana diukur dalam SWLS terlalu berfokus pada evaluasi pribadi serta mengabaikan faktor konteks sosial, yang bagi orang Indonesia merupakan hal esensial.

Religiositas juga merupakan variabel yang banyak diteliti di Indonesia dengan menggunakan alat ukur yang diadopsi dari konsep psikologi Barat. Salah satu alat ukur yang cukup banyak digunakan untuk mengukur tingkat religiositas ialah The Four Basic Dimensions of Religiousness Scale (4BDRS) (Saroglou, 2009). Meski dibandingkan alat ukur serupa lainnya, 4BDRS melibatkan partisipan lintas agama dari 14 negara, aspek ulayat dari religiositas bagi masyarakat Indonesia pada umumnya kurang dapat terwakili, misalnya: keputusan memakai jilbab (Arifah \& Usman, 2017; Mas'ud \& Widodo, 2015) atau atribut keagamaan lain dapat memberikan perspektif penting terhadap religiositas bagi beberapa masyarakat Indonesia.

Konstruk terakhir lainnya ialah mengenai katarsis. Katarsis merupakan usaha seseorang untuk mengekspresikan impuls di dalam diri yang berhubungan dengan perasaan, pengalaman, dan pikiran tidak menyenangkan. Menurut tradisi psikodinamik dan humanistik pada umumnya, katarsis dipercaya dapat menjadi strategi terapeutik yang baik untuk menunjang kesehatan mental seseorang (Henry, 1999). Meski relevansi konsep dalam konteks masyarakat Indonesia belum pernah diteliti secara sistematis, ada indikasi konsep ini kurang sesuai pada beberapa budaya di Indonesia yang cenderung memandang lebih baik untuk individu menerima dengan lapang dada (Pratiwi \& Suwanto, 2019), dibandingkan secara ekspresif mengutarakan perasaannya.

\section{Simpulan}

Alat ukur bagi sebuah penelitian berfungsi seperti lensa bagi kamera. Ia memberikan perspektif dan menentukan seakurat apa potret yang dihasilkan dalam menggambarkan objek yang dipotretnya. Fokus yang terlalu besar pada sisi statistik pada pengukuran psikologis dapat berdampak pada keterjebakan pengambilan kesimpulan yang keliru, reduksionistik, dan abai terhadap sisi ulayat dalam menginterpretasikan sebuah fenomena. Bagaimana pun, lensa yang salah tidak dapat menghasilkan gambar yang jernih.

Ketika faktor budaya dan keunikan konteks lokal turut dilibatkan, isu pengukuran menjadi lebih daripada sekadar persoalan matematika dan statistik. Maknanya lebih kaya, kontekstual, dan konsisten dalam merefleksikan dinamika psikologis masyarakat Indonesia yang sebenarnya. Baru-baru ini studi tentang kebahagiaan pernah dilakukan oleh Maulana, Khawaja, and Obst (2019) dengan benar-benar mengkonseptualisasikan arti bahagia menurut perspektif masyarakat Indonesia. Kita tentu berharap lebih banyak lagi studi-studi seperti ini untuk variabel-variabel lainnya sehingga dapat diperoleh lensa yang benar dalam memotret wajah psikologis masyarakat Indonesia.

\section{Daftar Pustaka}

Arifah, L., \& Usman, H. (2017). Pengaruh religiusitas, subjective norm dan perceived behavioral control terhadap keputusan Muslimah berhijab. Jurnal Middle East and Islamic Studies, 4(1), 61-72.

Diener, E., Emmons, R. A., Larsen, R. J., \& Griffin, S. (1985). The Satisfaction With Life Scale. Journal of Personality Assessment, $\quad 49(1), \quad$ 71-75. doi:10.1207/s15327752jpa4901_13

Domino, G., \& Domino, M. (2006). Psychological testing: An introduction (2nd ed.). Cambridge: Cambridge University Press.

Harrits, G. S. (2011). More than method?: A discussion of paradigm differences within mixed methods research. Journal of Mixed Methods Research, 5(2), 150166. doi:10.1177/1558689811402506 
Henry, J. (1999). Changing conscious experience: Comparing clinical approaches, practice and outcomes. British Journal of Psychology, 90, 587609.

Himawan, K. K. (2019). Either I do or I must: An exploration of the marriage attitudes of Indonesian singles. The Social Science Journal, 56(2), 220-227. doi:10.1016/j.soscij.2018.07.007

Himawan, K. K. (2020). Menikah adalah ibadah: Peran agama dalam mengkonstruksi pengalaman melajang di Indonesia. Jurnal Studi Pemuda, 9(2). doi:10.22146/studipemudaugm.56548

Mas'ud, N. A., \& Widodo, P. B. (2015). Religiusitas dan pengambilan keputusan memakai jilbab gaul pada mahasiswi Universitas Diponegoro. Jurnal Empati, 4(4), 309-314.

Maulana, H., Khawaja, N., \& Obst, P. (2019). Development and validation of the indonesian Well-being Scale. Asian Journal of Social Psychology, 22, 268280. doi:10.1111/ajsp.12366

Pratiwi, P. C., \& Suwanto, Y. (2019). Kontribusi Serat Wedhatama sebagai salah satu ajaran moral bagi Masyarakat Jawa. In S. E. Hafiz \& E. A. Meinarno (Eds.), Psikologi Indonesia (pp. 155-176).

Saroglou, V. (2009). The Four Basic Dimensions of Religiousness Scale. Unpublished manuscript. Catholic University of Louvain, Belgium.

Sarwono, S. W. (2012). Psikologi Ulayat. Jurnal Psikologi Ulayat, 1(1), 1-16. doi:10.24854/jpu12012-6

Tomás, J. M., Gutiérrez, M., Sancho, P., \& Romero, I. (2015). Measurement invariance of the Satisfaction With Life Scale (SWLS) by gender and age in Angola. Personality and Individual Differences, $\quad 85, \quad 182-186$. doi:10.1016/j.paid.2015.05.008

Wainer, H. (1987). The first four millennia of mental testing: From Ancient China to the computer age. Educational Testing Service Research Report(87), 34.

Wu, C.-H., Chen, L. H., \& Tsai, Y.-M. (2009). Longitudinal invariance analysis of the satisfaction with life scale. Personality and Individual Differences, 46, 396-401.

$\overline{\text { Jurnal Penelitian dan Pengukuran Psikologi, Vol. 10, No. 1, April } 2021}$ 